\title{
Novel Microstructure Mechanical Activated Nano Composites for Tissue Engineering Applications
}

\author{
Amirsalar Khandan ${ }^{1 *}$, Neriman Ozada ${ }^{1}$ and Ebrahim Karamian ${ }^{2}$ \\ ${ }^{1}$ Mechanical Engineering department, Eastern Mediterranean University, North Cyprus, Gazimağusa, TRNC, Mersin 10, Turkey \\ ${ }^{2}$ Department of Materials Engineering, Najafabad Branch, Islamic Azad University, Isfahan, Iran
}

\begin{abstract}
Nowadays, tricalcium phosphate TCP $\left(\mathrm{Ca}_{3}\left(\mathrm{PO}_{4}\right)_{2}\right)$ that belongs to the group of calcium phosphate $(\mathrm{CaPs})$ biomaterials as a hot topic of research for bone tissue repair applications. In this investigation, TCP powder was synthesized by mechanical activation (MA) method as a solid state process. The mixture was composed of a blend of pure calcite $\left(\mathrm{CaCO}_{3}\right)$ and silica amorphous $\left(\mathrm{SiO}_{2}\right)$ powder with $57 \%$ wt. and $43 \%$ wt., respectively. Then, the powder mixture milled by high energy ball mill with ball to powder ratio (BPR) $15: 1$ and rotation speed $600 \mathrm{rpm}$ for $10 \mathrm{~h}$. After then, the materials milled heated at three temperatures $900^{\circ} \mathrm{C}, 1000^{\circ} \mathrm{C}$ and $1100^{\circ} \mathrm{C}$ for $2 \mathrm{~h}$ in muffle furnace at the air atmosphere. X-ray diffraction (XRD), scanning electron microscopy (SEM) and BET technique performed on heated powders to characterize. According to XRD results, the patterns show that the phase TCP was just appeared in the mixture milled for $10 \mathrm{~h}$. In addition, based on modified Scherer equation the TCP crystalline size was determined $40 \mathrm{~nm}$. In fact, the present investigation indicated that TCP powder was composed of Nano-crystallite structure, 30-40 nm, can be prepared by MA method at $900^{\circ} \mathrm{C}$ or $1000^{\circ} \mathrm{C}$ to use as a new biomaterials for tissue engineering application.
\end{abstract}

Keywords: Synthesis; TCP; Ball Milling; Mechanical Activation; Nanostructure

\section{Introduction}

Calcium phosphates (CaPs) biomaterials are widely used as substitutes for auto genus bone grafts when bone reconstruction is considered [1-2]. CaPs such as hydroxyapatite $\left[\mathrm{HA} ; \mathrm{Ca}_{10}\left(\mathrm{PO}_{4}\right)_{6}(\mathrm{OH})\right.$ 2] and Tri-calcium phosphates [TCP; $\left.\mathrm{Ca}_{3}\left(\mathrm{PO}_{4}\right)_{2}\right]$ are remarkably biocompatible, provoke little if any inflammatory response, and generally are accepted to be bioactive and Osseo conductive when implanted into bone defects [3]. In orthopaedics a variety of biomaterials has been investigated and widely applied in bone-defect management, and skeletal tissue engineering, with many satisfactory clinical outcomes [4]. HA and TCP are bioactive, these biomaterials that have similar composition, structure close to mineral bone of human have good bioactivity [5,6]. HA-TCP based biomaterials can guide bone tissue growth, facilitate bone formation have been used clinically as bone substitutes. The bios activate material serves as a scaffold for new bone formation and increase the in growth of osteoprogenitor cells, capillaries, and per vascular tissue from the recipient bed. Biomaterials should participate in the continuous process of bone remodeling, and the implanted biomaterial should be gradually replaced at a rate comparable to that of in growth of newly formed bone [7]. Although, excellent bioactive ceramics such as hydroxyapatite $\left(\mathrm{Ca}_{10}\left(\mathrm{PO}_{4}\right)_{6}(\mathrm{OH})_{2,}\right.$ [8-10]. diopside $\left(\mathrm{CaMgSiO}_{6}\right)$ [11], akermanite $\left(\mathrm{Ca}_{2} \mathrm{MgSi}_{2} \mathrm{O}_{7}\right)$, hardystonite $\left(\mathrm{Ca}_{2} \mathrm{ZnSi}_{2} \mathrm{O}_{7}\right)$ [12], and forsterite $\left(\mathrm{Mg}_{2} \mathrm{SiO}_{4}\right)$ [13] bonds with hard tissues as well. Among these bioceramics, TCP is one typical bioactive ceramic which has shown great potential for bone tissue application. In the present investigation, the TCP powder was composed of Nano-crystallite structure can be prepared by mechanical activation (MA), solid state process, to use as a new biomaterials for medical and dental purposes [6-10].

\section{Materials and Methods}

Amount of raw materials required for synthesis of $10 \mathrm{~g}$ TCP sample was $5.7 \mathrm{~g}$ magnesia $(\mathrm{MgO})$ and $4.3 \mathrm{~g}$ silica. The raw materials milled by high energy milling with ball-to powder ratio 10:1 and rotation speed $600 \mathrm{rpm}$. The mixture milled was heated for 3 hours at three temperatures $\left(900^{\circ} \mathrm{C}, 1000^{\circ} \mathrm{C}\right.$ and $\left.1100^{\circ} \mathrm{C}\right)$ in the muffle furnace at the air atmosphere. Phase structure analysis was carried out by X-ray diffraction (XRD) (Philips X'Pert-MPD diffract meter with $\mathrm{Cu} \mathrm{K}$ radiation $(\lambda 1=0.15418 \mathrm{~nm})$ over the $2 \theta$ range of $10-90)$. The obtained experimental patterns were compared to the standards compiled by the Joint Committee on Powder Diffraction and Standards (JCDPS) which involved card (00-090169) for TCP. The crystallite size of prepared powders was determined using XRD patterns and modified Scherrer equation [14]. Scanning electron microscopy (SEM) analyses evaluations were performed using a LEO $435 \mathrm{VP}$ to investigate the morphology. Samples coated with Au by sputter spraying, low vacuum and $100-120 \mathrm{~V}$ accelerating voltage. The specific BET surface area of TCP powder has been done by Kelvin B100.

\section{Modified Scherrer equations}

The modified Scherrer equation can provide the advantage of decreasing the sum of absolute values of errors, $\Sigma( \pm \Delta \ln \beta)^{2}$, and producing a single line through the points to give a single value of intercept $\ln K \lambda / \mathrm{L}$. At this sample, Figure 1 , the linear regression plot is obtained as $y=3.355 X-5.540$. This is equivalent to $\operatorname{Ln} \beta=\ln (1 /$ $\operatorname{Cos} \Theta)+\ln (\mathrm{k} \lambda / \mathrm{L})($ Eq. 1). From this line, the intercept is -5.540 and $\mathrm{e}$ ${ }^{-5.540}=\mathrm{K} \lambda / \mathrm{L}$ and $\mathrm{L}=35 \mathrm{~nm}$. So, TCP crystallite size average is $40 \mathrm{~nm}$ [5] (Figure 1).

According to the same way, the TCP phase crystallite size for the samples heated at $1000^{\circ} \mathrm{C}$ and $1100^{\circ} \mathrm{C}$ are 40 and $50 \mathrm{~nm}$, respectively.

*Corresponding author: Amirsalar Khandan, Mechanical Engineering department Eastern Mediterranean University, North Cyprus, Gazimagusa, TRNC, Mersin 10, Turkey, E-mail: amirsalar.khandan@cc.emu.edu.tr

Received: January 28, 2015; Accepted: March 10, 2015; Published: March 17 2015

Citation: Khandan A, Ozada N, Karamian E (2015) Novel Microstructure Mechanical Activated Nano Composites for Tissue Engineering Applications. J Bioengineer \& Biomedical Sci 5: 143. doi:10.4172/2155- 9538.1000143

Copyright: (c) 2015 Khandan A, et al. This is an open-access article distributed under the terms of the Creative Commons Attribution License, which permits unrestricted use, distribution, and reproduction in any medium, provided the original author and source are credited. 
Citation: Khandan A, Ozada N, Karamian E (2015) Novel Microstructure Mechanical Activated Nano Composites for Tissue Engineering Applications. J Bioengineer \& Biomedical Sci 5: 143. doi:10.4172/2155- 9538.1000143

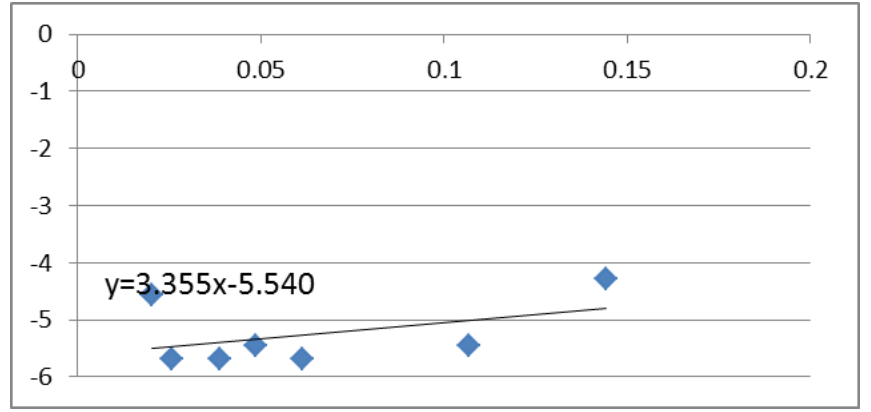

Figure 1: Plot of $\operatorname{In} \beta$ vs. $\operatorname{Ln}(1 / \operatorname{Cos} \theta)$ of TCP sample heated at $900^{\circ} \mathrm{C}$ for $2 \mathrm{~h}$.
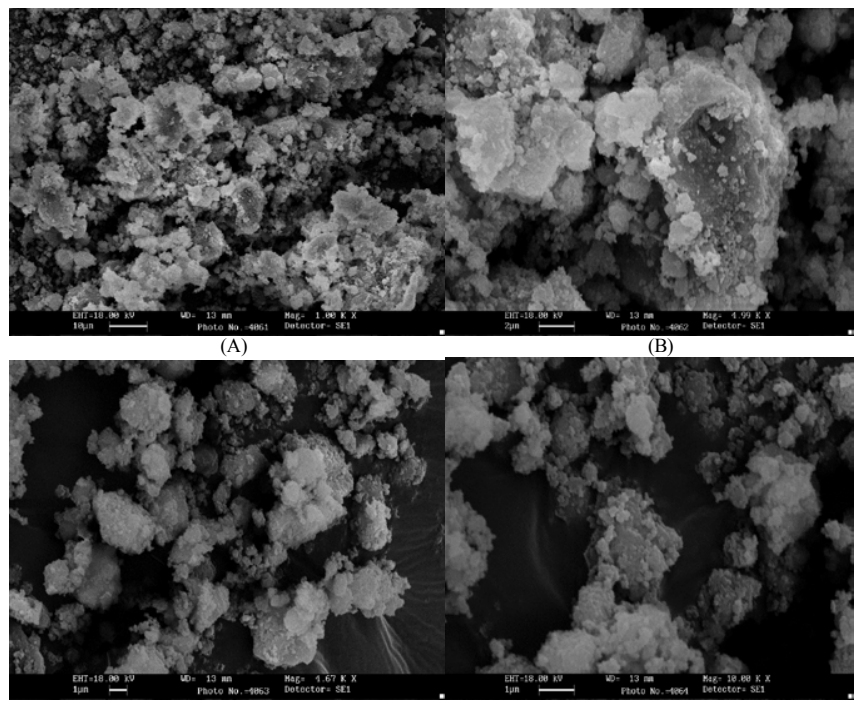

(C)

(D)

Figure 2: SEM micrograph of the materials milled and then heated at $900^{\circ} \mathrm{C}$ $1000 \mathrm{C}, 1100^{\circ} \mathrm{C}$ for 2 hours.

So, the average crystallite size of TCP phase obtained is approximately $30-50 \mathrm{~nm}$.

\section{Results}

\section{SEM micrographs}

Figure 2 show the SEM micrograph the materials milled before and after heating. Figure 2 shows the SEM micrographs of the $2 \mathrm{~h}$ ballmilled powder after annealing at $1000^{\circ} \mathrm{C}$ for $1 \mathrm{~h}$. SEM observations showed that TCP has non-spheroid crystals; however, the crystal sizes of TCP is in the order of microns, and some particles are spherical whereas others have sharp shapes (Figure 2a-2c). The agglomerated particles are composed of very fine particles (Figure 2).

\section{XRD Results}

Figures 3 and 4 show the XRD patterns of the materials mixture milled heated at three temperatures.

\section{BET results}

The specific surface area of the prepared powder was calculated from the $\mathrm{N}_{2}$ gas adsorption isotherms using the multipoint BET technique The average particle size of the prepared powder, assuming that the particles synthesized were spheroid, was calculated as shown in Equation 2.

$$
\mathrm{D}=6000 /\left(\mathrm{S}_{\mathrm{BET}} * \mathrm{~d}\right)
$$

Where $\mathrm{d}$ and $\mathrm{D}$ are true density $\left(\mathrm{g} / \mathrm{cm}^{3}\right)$ and the average particle size (micron) of materials mixture milled, respectively. The specific surface area determined by BET (Figure $5 \mathrm{~b}$ ) was $4.5 \mathrm{~m}^{2} / \mathrm{g}$. Therefore, the particles size was estimated about $530 \mathrm{~nm}$. In fact, the powder mixture is micron size (Figure 5).

\section{Time and energy transfer}

The minimum synthesis ball milling time or best operational performance of milling process is given by equation 3 :

$$
t=B \times m_{c h} \times f
$$

Which B is constant depending on density of balls, elastic and inelastic collisions as well as the heat released by the reactions between the raw materials; $m_{c h}$ is the mass of the powder charge which is determined by ball to powder weight ratio (BPR); and $\mathrm{f}$ is the cost function of the problem so that by minimizing the $f$, the synthesis time is also minimized. Therefore, in such a scenario, all parameters including $\mathrm{B}$ and f play a fundamental role and they have to be optimized

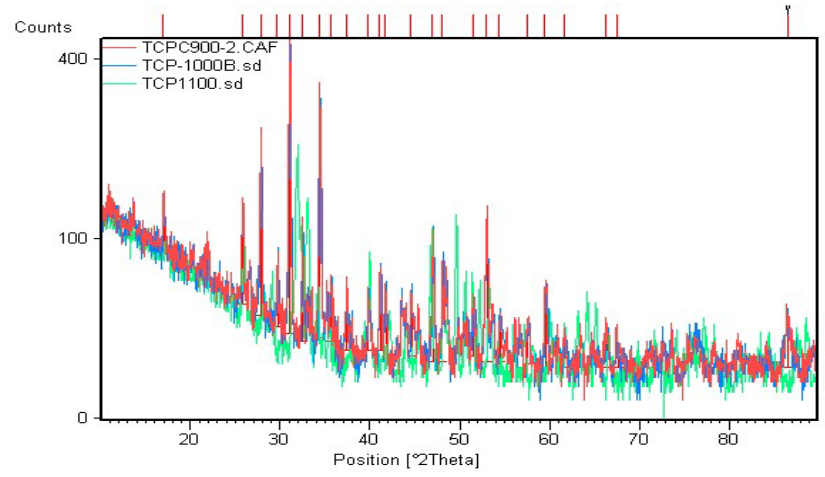

Figure 3: Comparison of XRD pattern of the materials mixture milled and then heated at three temperatures for $2 \mathrm{~h}$.

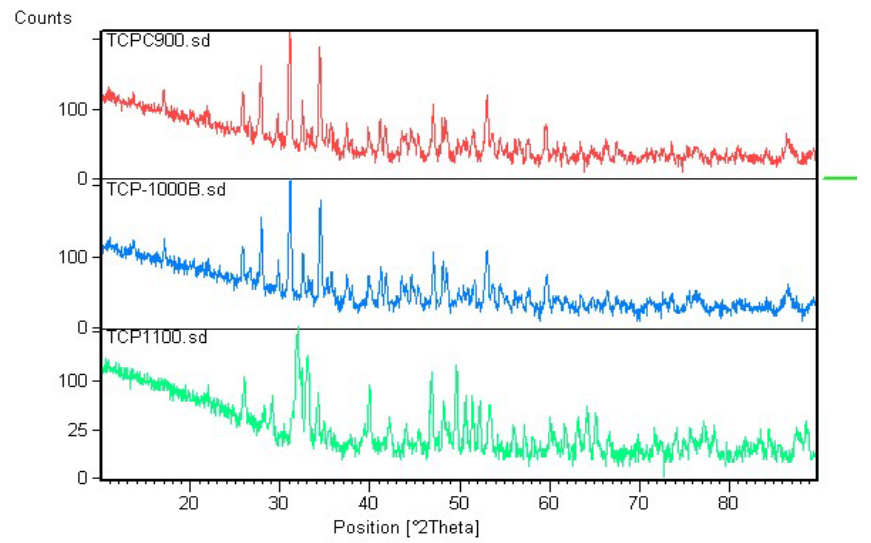

Figure 4: Intensity of sharp peaks of synthesis powder is between $25-55^{\circ}$. 


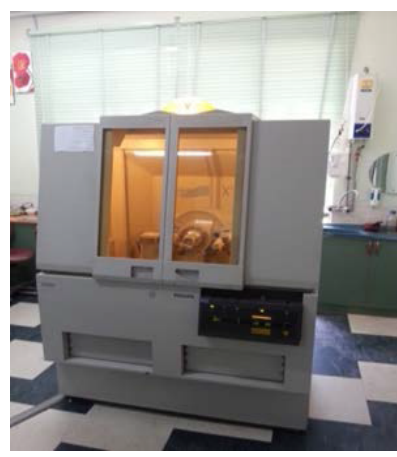

(a)

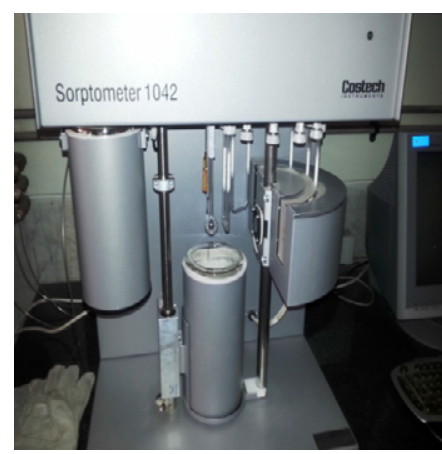

(b)

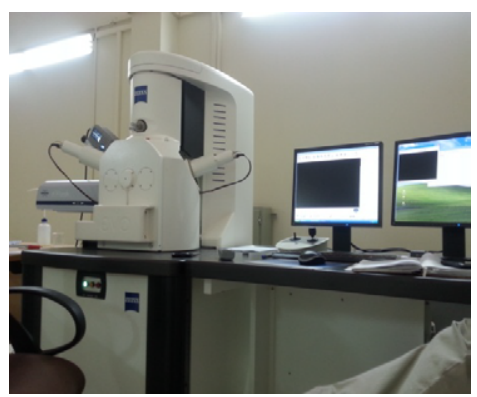

(c)

Figure 5: Equipment used in fabrication of TCP (a) XRD, (b), BET and (c) SEM equipment's in advanced materials research Centre of IAUN University.
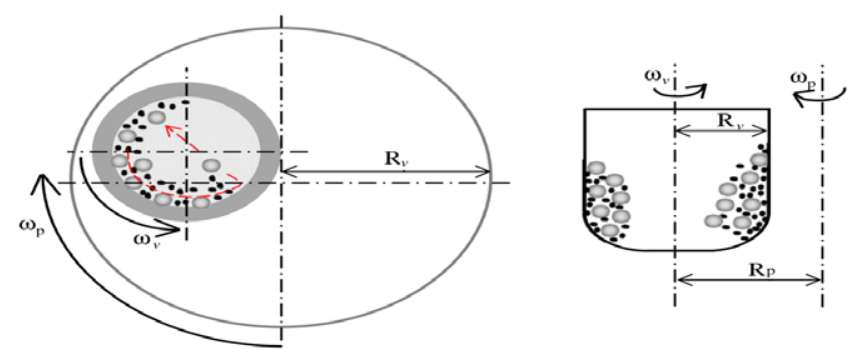

Figure 6: Schematic of mechanical activation (MA) method and $R_{v}, W p, W v$ are ball mill parameters.

in order to achieve the minimum synthesis time or best operational performance of ball milling process. This calculation also proved that the optimum time to produce TCP by MA method (Figure 6) is $10 \mathrm{~h}$ ball milling.

\section{Discussion}

According to the XRD patterns, TCP phase was synthesized in all the samples heated at three temperatures. Based on the previous studies, TCP phase was synthesized at above $1000^{\circ} \mathrm{C}$. But, in this method TCP phase have been achieved at $900^{\circ} \mathrm{C}$ by using mechanical activation. The samples heated at $900^{\circ} \mathrm{C}$ and $1000^{\circ} \mathrm{C}$ have same patterns. Whereas, the pattern belong to the sample heated at $1100^{\circ} \mathrm{C}$ has somewhat right shift in comparison to another patterns. Therefore, the sample heated at $900^{\circ} \mathrm{C}$ is the best sample containing TCP phase. Bio-ceramics and especially TCP plays a key role as bone tissue engineering and biomaterials in clinical fields. However, the use of conventional materials like HA which is economical cost is limited because of their essential properties. Bovine bone mimicked with TCP structure and produced a proper bioactive coating. In spite of the fact that in other studies, researches working on different types of HA derivate from seashells (sHA) and eggshells (eHA), to compare the bone regeneration ability. Some other types of HA is that, biphasic calcium phosphate (BCP) consisting of HA having excellent bioactivity and BCP having high biodegradability [15-17].

\section{Conclusions}

In conclusion, TCP phase have been synthesized at $900^{\circ} \mathrm{C}$ by materials mixture MA method. Whereas, based on the previous studies, TCP phase was synthesized at above $1000^{\circ} \mathrm{C}$. However, the use of conventional materials likes HA and TCP which is economical cost is limited because of their essential properties.

\section{Acknowledgment}

The authors would like to extend their gratitude for the supporting provided by Najafabad Branch, Islamic Azad University, and Isfahan, Iran.

\section{References}

1. Blokhuis TJ, Wipperman BW, Den Boer FC, van Lingen A, Patka $P$, et al. (2000) Resorbable calcium phosphate particles as a carrier material for bone marrow in an ovine segmental defect. J Biomed Mater Res 51: 369-375.

2. Burchardt H (1983) The biology of bone graft repair. Clin Orthop Relat Res 174: 28-42.

3. Dorozhkin SV (2007) Bioceramics based on calcium orthophosphates. Glass and Ceramics 64: 442-447

4. Kamitakahara MC, Ohtsuki, Miyazaki T (2008) Review paper: behavior of ceramic biomaterials derived from tricalcium phosphate in physiological condition. J Biomater Appl 23: 197-212.

5. Tancred D, Carr A, McCormack BAO (1998) Development of a new synthetic bone graft. Journal of Materials Science: Materials in Medicine 9: 819-823.

6. Wang Y, Ni M, Tang PF, Li G (2009) Novel application of HA-TCP biomaterials in distraction osteogenesis shortened the lengthening time and promoted bone consolidation. J Orthop Res 27: 477-482.

7. Jarcho M (1981) Calcium phosphate ceramics as hard tissue prosthetics Clinical orthopaedics and related research 157: 259-278.

8. Karamian E, Khandan A, Eslami M, Gheisari H, Rafiaei N (2014) Investigation of HA Nanocrystallite Size Crystallographic Characterizations in NHA, BHA and HA Pure Powders and their Influence on Biodegradation of HA. Advanced Materials Research 829: 314-318.

9. Karamian E, Motamedi MRK, Mirmohammadi K, Soltani P, Khandan A (2014) Correlation Between Crystallographic Parameters and Biodegradation Rate of Natural Hydroxyapatite in Physiological Solutions. Indian J. Sci. Res 4: 92-99.

10. Khandan A, Karamian E, Bonakdarchian M (2014) Mechanochemical synthesis evaluation of nanocrystalline bone-derived bioceramic powder using for bone tissue engineering. Dental Hypotheses 5: 155-161.

11. Karamiana E, Khandan A, Rafiee N, Eslami M (2014) Synthesis of NanoCrystallite Diopside by Mechanical Activation to Use Medical Applications. International Conference on Nanostructures, Kish Island, Iran.

12. Lu H, Kawazoe N, Tateishi T, Chen G, Jin X, et al. (2010) In vitro proliferation and osteogenic differentiation of human bone marrow-derived mesenchymal stem cells cultured with hardystonite (Ca2ZnSi 2O7) and $\beta$-TCP ceramics. J Biomater Appl 25: 39-56.

13. Kharaziha M, Fathi M (2009) Synthesis and characterization of bioactive forsterite nanopowder. Ceramics International 35: 2449-2454.

14. Monshi A, Foroughi MR, Monshi MR (2012) Modified Scherrer equation to estimate more accurately nano-crystallite size using XRD. World Journal of Nano Science and Engineering 2: 154-160.

15. Lee SW, Balazsi C, Balazsi K, Hyun Seo D, Kim HS, et al. (2014) Comparative Study of hydroxyapatite prepared from seashells and eggshells as a bone graft material. Tissue Engineering and Regenerative Medicine 11: 113-120. 
Citation: Khandan A, Ozada N, Karamian E (2015) Novel Microstructure Mechanical Activated Nano Composites for Tissue Engineering Applications. J Bioengineer \& Biomedical Sci 5: 143. doi:10.4172/2155- 9538.1000143

Page 4 of 4

16. Seok HS, Herr Y, Chung JH, Shin S, Han J, et al. (2014) The effect of composite graft with deproteinized bovine bone mineral and mineralized solvent-dehydrated bone on exophytic bone formation in rabbit calvarial model.

Tissue Engineering and Regenerative Medicine 11: 467-475.
17. Kim HJ, Park IK, Kim JH, Cho CS (2012) Gas foaming fabrication of porous biphasic calcium phosphate for bone regeneration. Tissue Engineering and Regenerative Medicine 9: 63-68. 